CIHM

Microfiche Series (Monographs)
ICMH

Collection de microfiches (monographies)

Canadian Institute for Historical Microreproductions / Institut canadien de microreproductions historiques
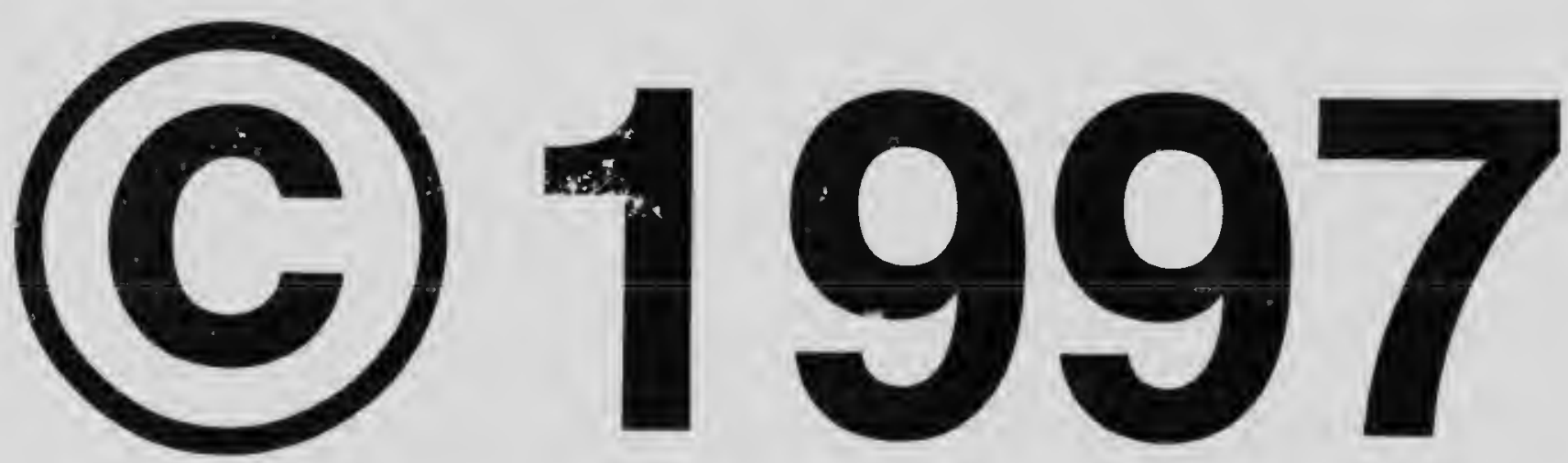


\section{Technical and Bibliographic Notes / Notes techniques et bibliographiques}

The Institute has attempted to obtain the best original copy available for filming. Features of this copy which may be bibliographically unique, which may alter any of the images in the reproduction, or which may significantly change the usual method of filming are checked below.

\section{Coloured covers /}

Couverture de couleur

Covers damaged /

Couverture endommagée

Covers restored and/or laminated /

Couverture restaurée etlou pelliculée

Cover title missing / Le titre de couverture manque

Coloured maps / Cartes géographiques en couleur

Coloured ink (i.e. other than blue or black) I

Encre de couleur (i.e. autre que bleue ou noire)

Coloured plates and/or illustrations /

Planches et/ou illustrations en couleur

Bound with other material /

Relié avec d'autres documents

Only edition available /

Seule édition disponible

Tight binding may cause shadows or distortion along interior margin / La reliure serrée peut causer de l'ombre ou de la distorsion le long de la marge intérieure.

Blank leaves added during restorations may appear within the text. Whenever possible, these have been omitted from filming / II se peut que certaines pages blanches ajoutées lors d'une restauration apparaissent dans le texte, mais, Iorsque cela était possible, ces pages n'ont pas été filmées.

Additional comments /

Commentaires supplémentaires:
L'Institut a microfilmé le meilleur exemplaire qu'il lui a été possible de se procurer. Les détails de cet exemplaire qui sont peut-être uniques du point de vue bibliographique, qui peuvent modifier une image reproduite, ou qui peuvent exiger une modification dans la méthode normale de filmage sont indiqués ci-dessous.

Coloured pages / Pages de couleur

Pages damaged / Pages endommagées

Pages resiored and/or laminated /

Pages restaurées et/ou pelliculées

Pages discoloured, stained or foxed /

Pages décolorées, tachetées ou piquées

Pages detached / Pages détachées

Showthrough / Transparence

Quality of print varies /

Qualité inégale de l'impression

Includes supplementary material /

Comprend du matériel supplémentaire

Pages wholly or partially obscured by errata slips, tissues, etc., have been refilmed to ensure the best possible image / Les pages totalement ou partiellement obscurcies par un feuillet d'errata, une pelure, etc., ont été filmées à nouveau de façon à obtenir la meilleure image possible.

Opposing pages with varying colouration or discolourations are filmed twice to ensure the best possible image / Les pages s'opposant ayant des colorations variables ou des décolorations sont filmées deux fois afin d'obtenir la meilleure image. possible.

This item is filmed at the reduction ratio checked below /

Ce document est filmó au taux de réduction indiqué ci-dessous.

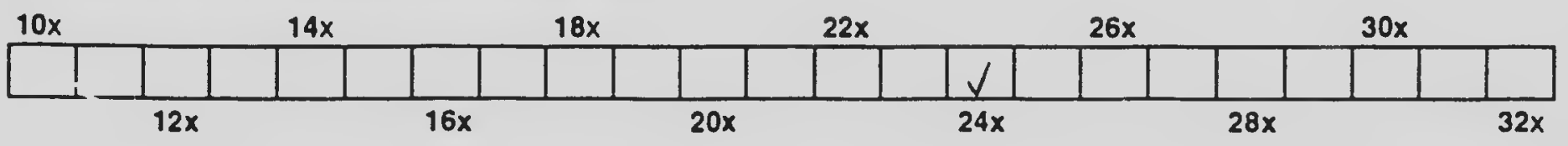


The copy filmed here has been reproduced thanks to the generosity of:

Library

Agriculture Canada

The images appearing here are the best quality possible considering the condition and legibility of the original copy and in keeping with the filming contract specifications.

Original copies in printed paper covers are filmed beginning with the front cover and ending on the last page with a printed or illustrated impres. sion, or the back cover when appropriate. All other original copies are filmed beginning on the first page with a printed or illustrated impres. sion, and ending on the last page with a printed or illustrated impression.

The last recorded frame on each microfiche shall contrin the symbol $\rightarrow$ (meaning "CON. TINUED"), or the symbol $\nabla$ (meaning "END"). whichever applies.

Maps, plates, charts, etc., may ba filmed at different reduction ratios. Those too large to be entirely included in one exposure are filmed beginning in the upper left hand corner, left to right and top to bottom, as many frames as required. The following diagrams illustrate the method:
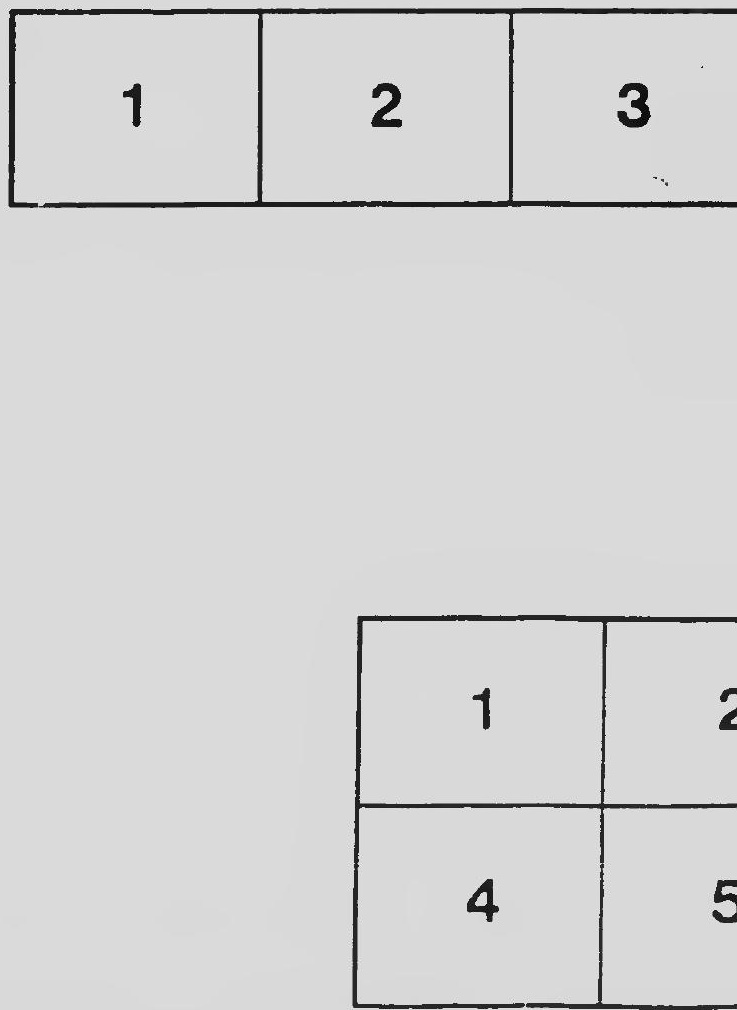
L'exemplaire filmo fut reproduit grâce à la générosité de:

\section{Bibliotheque}

Agriculture Canada

Les images suivantes ont 6t 6 reproduites avec le plus grand soin, compte tenu de la condition et de la netteté de l'exemplaire filmó, et en conformite avec les conditions du contrat de filmage.

Les exemplaires originaux dont la couverture en papier est Imprimée sont filmés en commençant per le premler plat et en terminant soit par la dernibre page qui comporte une empreinte d'impresslon ou d'illustration, soit par le second plat, selon le cas. Tous les autres exemplaires originaux sont filmós en commençant par la première page qui comporte une empreinte d'impresslon ou d'illustration et en terminant par la dernidre page qul comporte une telle emprelnte.

Un des symboles sulvants apparaitra sur la dernlere Image de chaque microflche, selon le cas: lo symbole $\rightarrow$ signifle "A SUIVRE", le symbole $\nabla$ signifle "FIN".

Les cartes, planches, tableaux, etc., peuvent ôtre filmós des taux de róduction diffórents.

Lorsque lo document est trop grand pour etre reprodult on un seul cllch6, il est filmb partir de l'angle supérieur gauche, de gauche à droite. et de haut en bas, en prenant le nombre d'images núcessaire. Les diagrammes suivants illustrant la méthode.

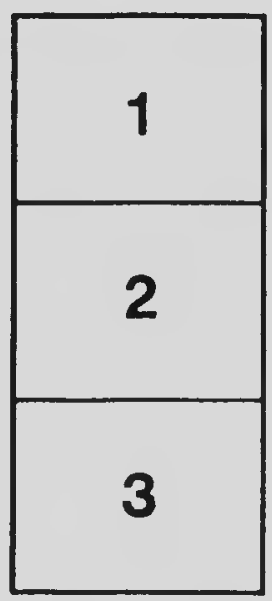

\begin{tabular}{|l|l|}
\hline 2 & 3 \\
\hline 5 & 6 \\
\hline
\end{tabular}




\section{MICROCOPY RESOUUTION TEST CHART}

(ANSI and ISO TEST CHART Na 2)
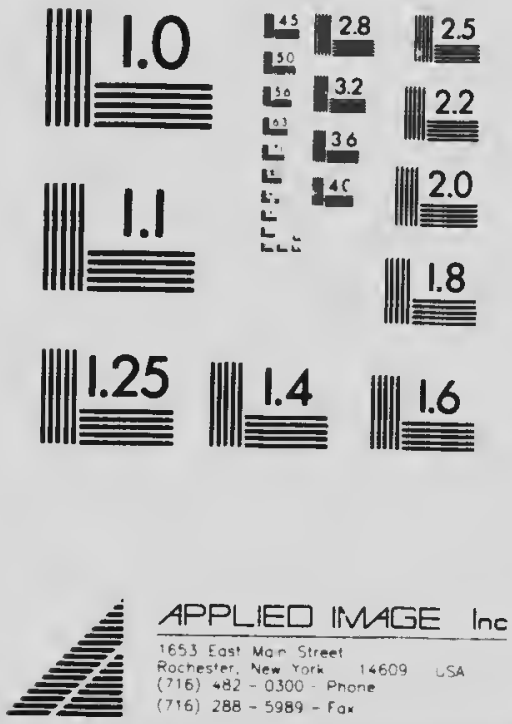


\title{
HOW TO RID A HENHOUSE OF MITES
}

\author{
HY

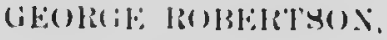 \\ l.suivtuml.
}

In the warm woather there ure frenuent impuirius as to why heus stop laying lı some cases the hens hive hid very well all setson. Int suldenly the egre vield hitgin. to fall off aud sometimes conises entirely.

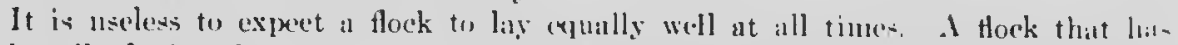

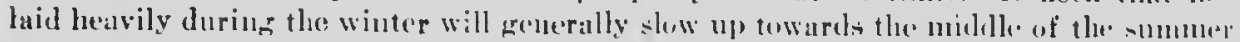

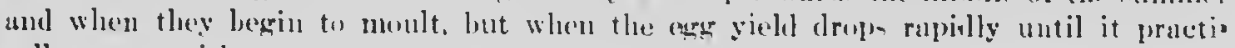

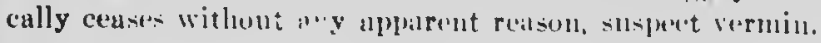

\section{Rt:.1) UITr:.}

Of all the many varieties ut vermin that infe-s fuwl, the Red Mite is the must

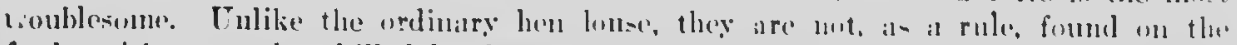

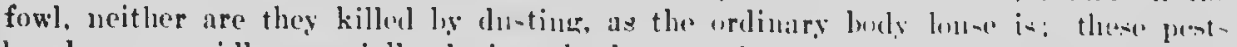

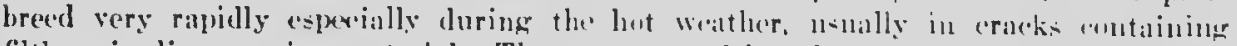
filtl or in dirty nesting material. They aro not rod in enlour as is popularly - mplumel.

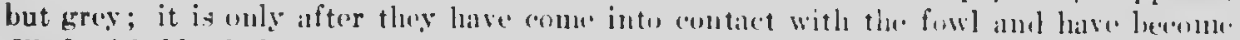

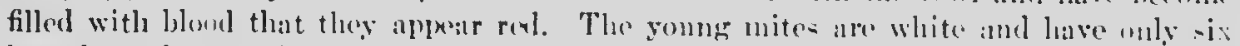

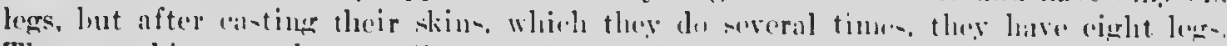

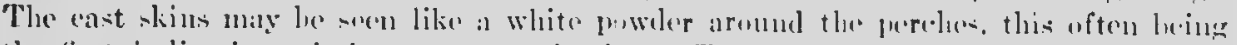

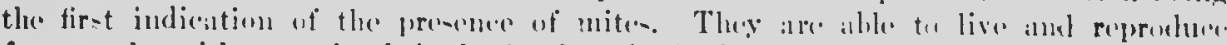
for months without animal foul. the fir-t find of the sumer probihly leving fiith or

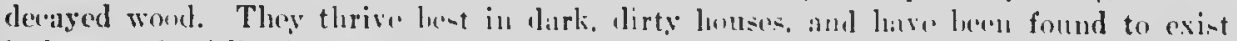

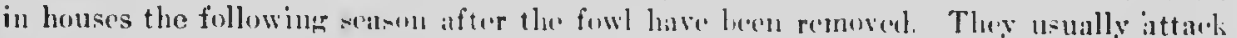
the lirds at night. lut aro - -

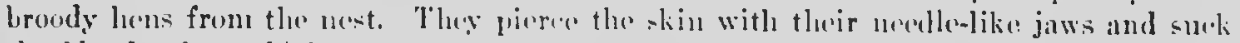
the bleod. after which they retire to the selnsion of the crates and ereviens of thu

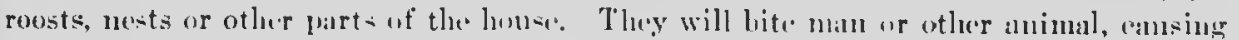
severe irritation, lat they mever romain un them for amy lonegth of times.

RE.MFHES

It tho fuwl ure nut doing woll and un examination are thimor than ther should be, is slisp linkout shomlel he kept for mites. It night tley may les seen either on

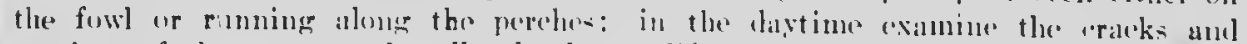
crevioes of the roosta aml walls "losely. ur lift the roosts alul eximine tlos plares

\section{DOMINION EXPERIMENTAL FARMS.}

J. H. GRISDALE, B.Agr.. Director.
F. C. ELFORD,

Dominion Poultry Husbandman.

EXHIBITION CIRCULAR No. 85. 
where they enme in enturt with the supports. If mites are found to lo present, the first step in bani-hing them is to give the house nthough cleaning. Remove all druppings and old nesting material, s(rape and sweep out cerery particlo of dirt and lurn it. Then if gou are so fortmately situted that you lave water pressuro at culir conmund, turn on the lose with as mueh pressure us gon ean get, foreing the Witur into esery erack; if as is the (ase all most farms, you cannot uso this meiliod it is advisnble to scrub down the malls with a lirnst: or old brown, hut in any case they :hould be thuroughly spruyed or painted with a good strongr disinfectant. This wash

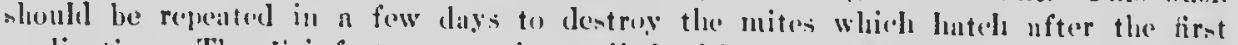
"ppliention. The disinfertant may be applied with un hand spray-punp or, if suld is

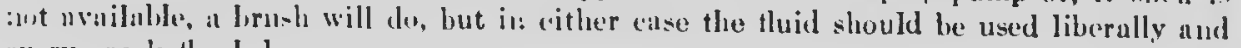
every arack tlooded.

\section{MSINFRTTITS.}

Fresh air and sunlight are wouderful disinfectants and, combincel with cleanlines-s. nre preventatives against must of the ills of the poultry surd.

One of the very best disinfertunts to use agninit mites is made as follows: bissolve one pound and a half of concentrated lye in as small a gmantity of witur as

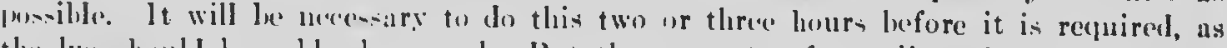

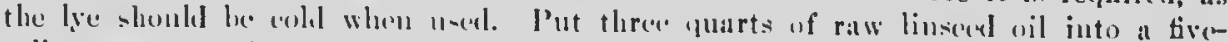

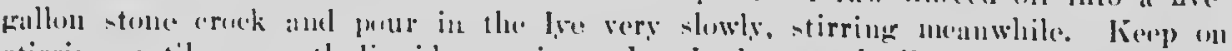

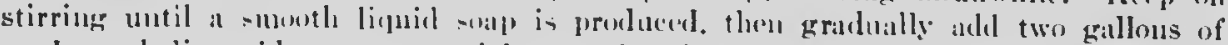

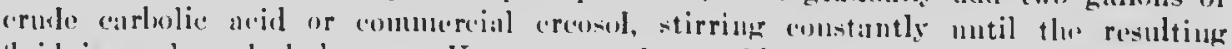

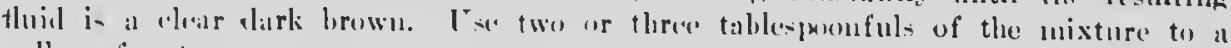
frallon of witt'r.

The forchroing is offered as a must effective remedre agrainst mites: lut those who reward the proparation of the mixture as two much work may use al gent strong solu.

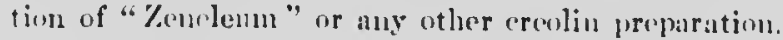

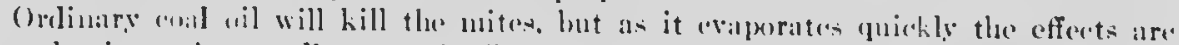

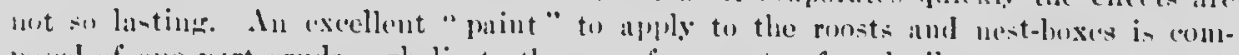

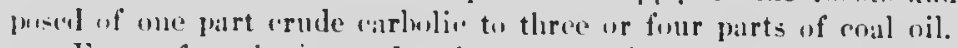

Even after the honte has becol eleaned, the cranks in the ronts and nest-boxes: slould le thooded at regular intersils throughout the summer eitluer with the forementinnerl "paint" "ur with cual oil. This will go far tu keep the pusts in cheek, but it must be rogarden simply as a cheok, and the thorough or annual housc-cleaning dereribed above put into affect as sonou als ponsiblu.

To facilitate the ease with which this homededeaniug is donc, all fixtures such at ronsts or ne-t-boxes thonlel be made movable. If they are stationary at present. akintage should be taken of the first rainy day to change them. It will be time well spent.

Published by autherity of Hon. MARTIN BURRELL, Minister of Agriculture, Ottawa, On 


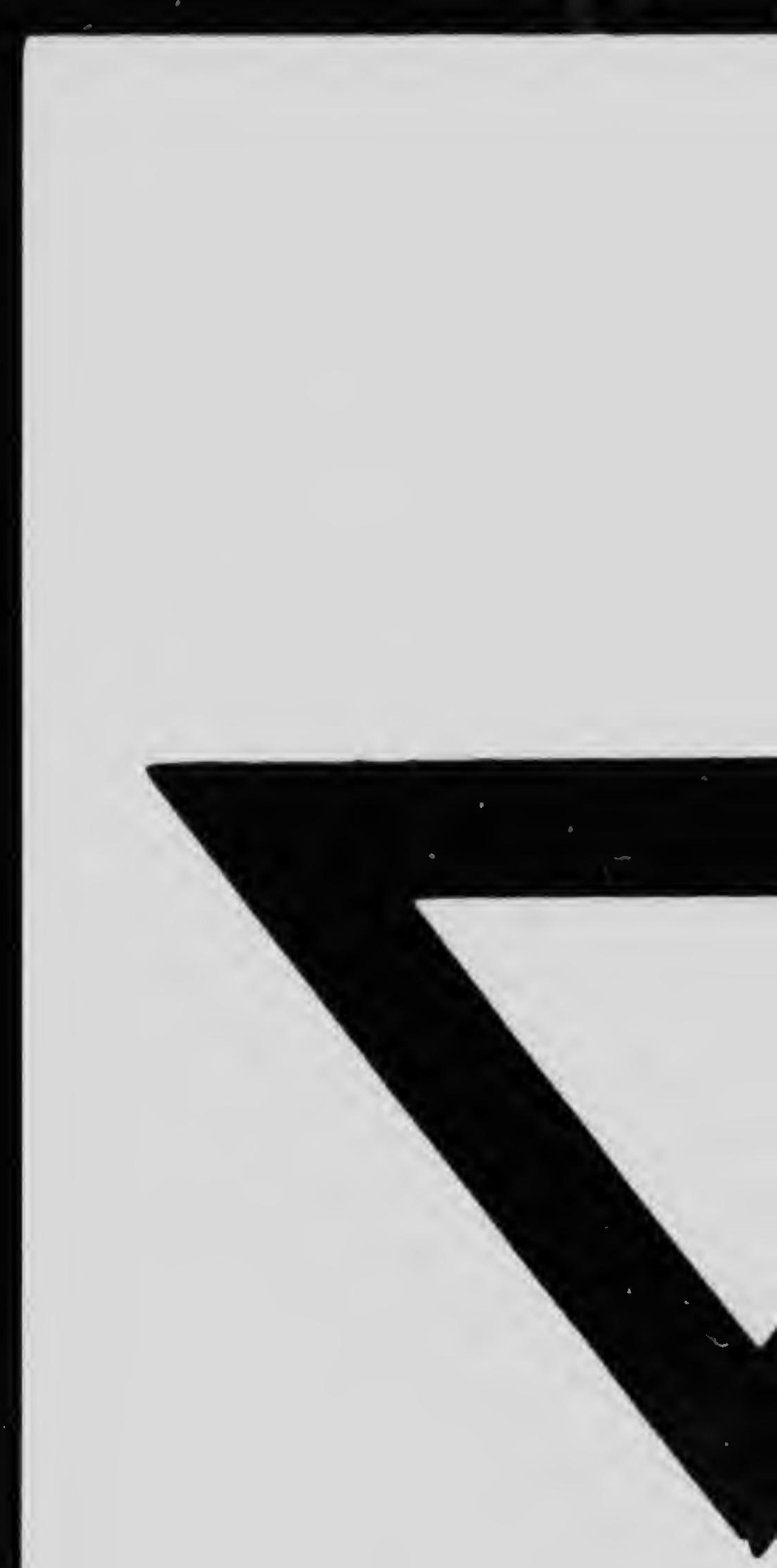




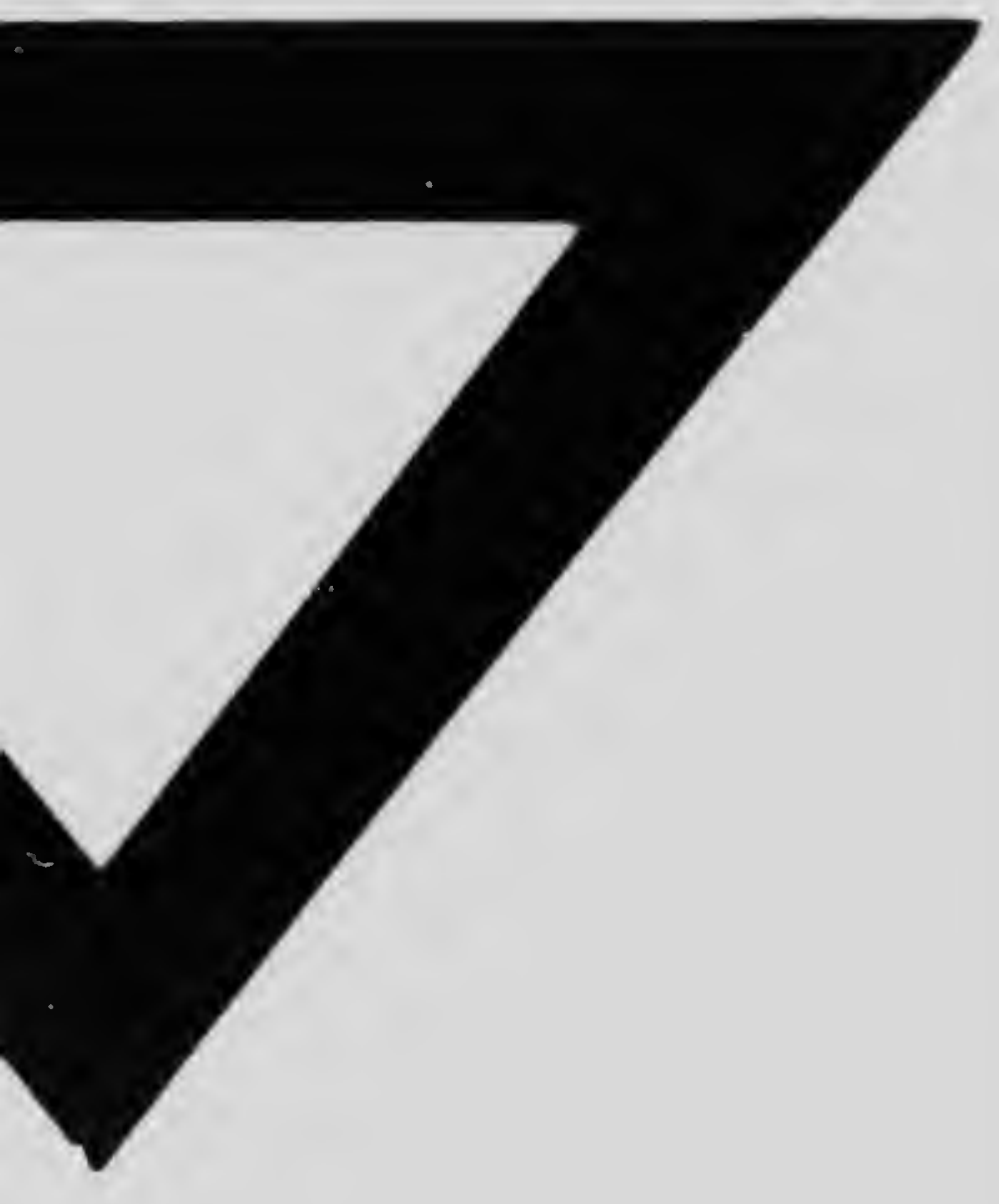

